\title{
Rediscovery of the hispid hare (Caprolagus hispidus) in Chitwan National Park, Nepal after three decades
}

Bed Bahadur Khadka ${ }^{\dagger, 1}$, Bhupendra Prasad Yadav ${ }^{2}$, Nurendra Aryal ${ }^{1}$, Achyut Aryal ${ }^{\dagger, 3,4,5}$

\begin{tabular}{|c|c|}
\hline SUMMARY & Conservation Note \\
\hline $\begin{array}{l}\text { The critical endangered hispid hare (Caprolagus hispidus) was first recorded as } \\
\text { present in Chitwan, Bardiya and Shuklaphanta National Parks of Nepal in } 1984 . \\
\text { Since then, the species was recorded only in Bardiya and Suklaphanta National } \\
\text { Parks. For more than three decades, it had not been observed in Chitwan National } \\
\text { Park (CNP), where it was consequently considered extinct. In January 2016, a new } \\
\text { recording for the hispid hare took place in CNP, placing that rare mammal again } \\
\text { within CNP mammal assemblages. We reported the first photographic confirmation } \\
\text { of the presence (30 Jan 2016) of the species in the CNP after 1984. The presence of } \\
\text { hispid hare is confined to isolate patched of grassland of the national park. The } \\
\text { population of the hispid hare is rapidly declining due to anthropogenic pressure and } \\
\text { grassland fire from its distributed range (only found in Nepal, India, and Bhutan). } \\
\text { Therefore, further study about their presence-absence, population status need to do } \\
\text { throughout the grassland of the low land of Nepal including the newly rediscovering } \\
\text { park. }\end{array}$ & 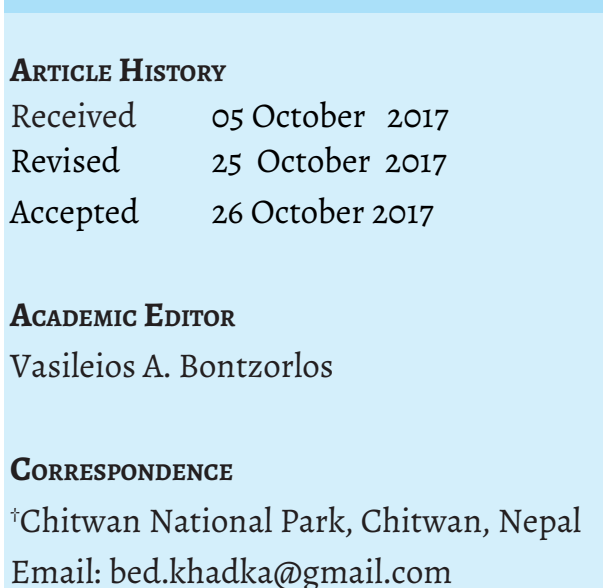 \\
\hline $\begin{array}{l}\text { KeYwoRDs Hipsid hare, Chitwan National Park, new records, small mammals } \\
\text { (1) }\end{array}$ & $\begin{array}{l}\text { Department of Forest and Resource } \\
\text { Management, Toi Ohomai Institute of } \\
\text { Technology, Rotorua 3046, New Zealand } \\
\text { E-mail: savefauna@gmail.com }\end{array}$ \\
\hline $\begin{array}{l}\text { "The rediscovery of a species is a good piece of news, but species may still on the brink of ex- } \\
\text { tinction" }\end{array}$ & \\
\hline $\begin{array}{l}\text { Author Contribution BBK, BPY, NA collected data and wrote the first draft. AA } \\
\text { edited, reviewed and finalise the manuscript. }\end{array}$ & \\
\hline $\begin{array}{l}\text { COMPETING INTEREST Authors declare no competing interest. } \\
\text { Funding Not applicable }\end{array}$ & \\
\hline
\end{tabular}

${ }^{1}$ Chitwan National Park, Chitwan, Nepal. Email: bed.khadka@gmail.com; ${ }^{2}$ Department of National Parks and Wildlife Conservation Kathmandu, Nepal. Email: bhupendra.dnpwc@gmail.com; ${ }^{3}$ Department of Forest and Resource Management, Toi Ohomai Institute of Technology, Rotorua 3046, New Zealand; ${ }^{4}$ Charles Perkins Centre, School of Life and Environmental Sciences, Faculty of Science, The University of Sydney, Sydney, Australia; ${ }^{5}$ Nature First Nepal, Kathmandu, Nepal. Email: savefauna@gmail.com

\section{Background}

The hispid hare is currently listed as a critically endangered species (Maheswaran and Smith 2008). The hare's historic range extends from the southern Himalayan foothills in Uttar Pradesh (India) through Nepal and into West Bengal to Assam (India), reaching southwards as far as Dacca in Bangladesh. However, its current distribution only includes the isolated tropical grasslands of Nepal, India and Bhutan only (IUCN 2008). Actual knowledge about the hare's population status and its ecology, throughout its distribution range still remains largely unexplored (Bell 1987, Yadav et al. 2008, Aryal and Yadav 2010, Aryal et al. 2012, Tandon et al. 2013, Nath and Machary 2015).
Since 1980's, the Government of Nepal (Department of National Parks and Wildlife Conservation [DNWPC]) has been placing continuous effort into realizing a presence-absence survey (using camera traps, transects surveys, etc.) in various lowland protected areas of Nepal. Emphasis was given of course on the tiger (Panthera tigris) population. Within the framework of this three-decade survey and monitoring of CNP grasslands and fauna, the presence of hispid hare was re-confirmed in CNP.

\section{The Recodiscovery}

The individual of hispid hare was observed at Sukhibhar in the CNP on 30 January, 2016 (Figures 1 \& 2). Sukhibhar lies on the west of the park headquarters at Kasara (in 


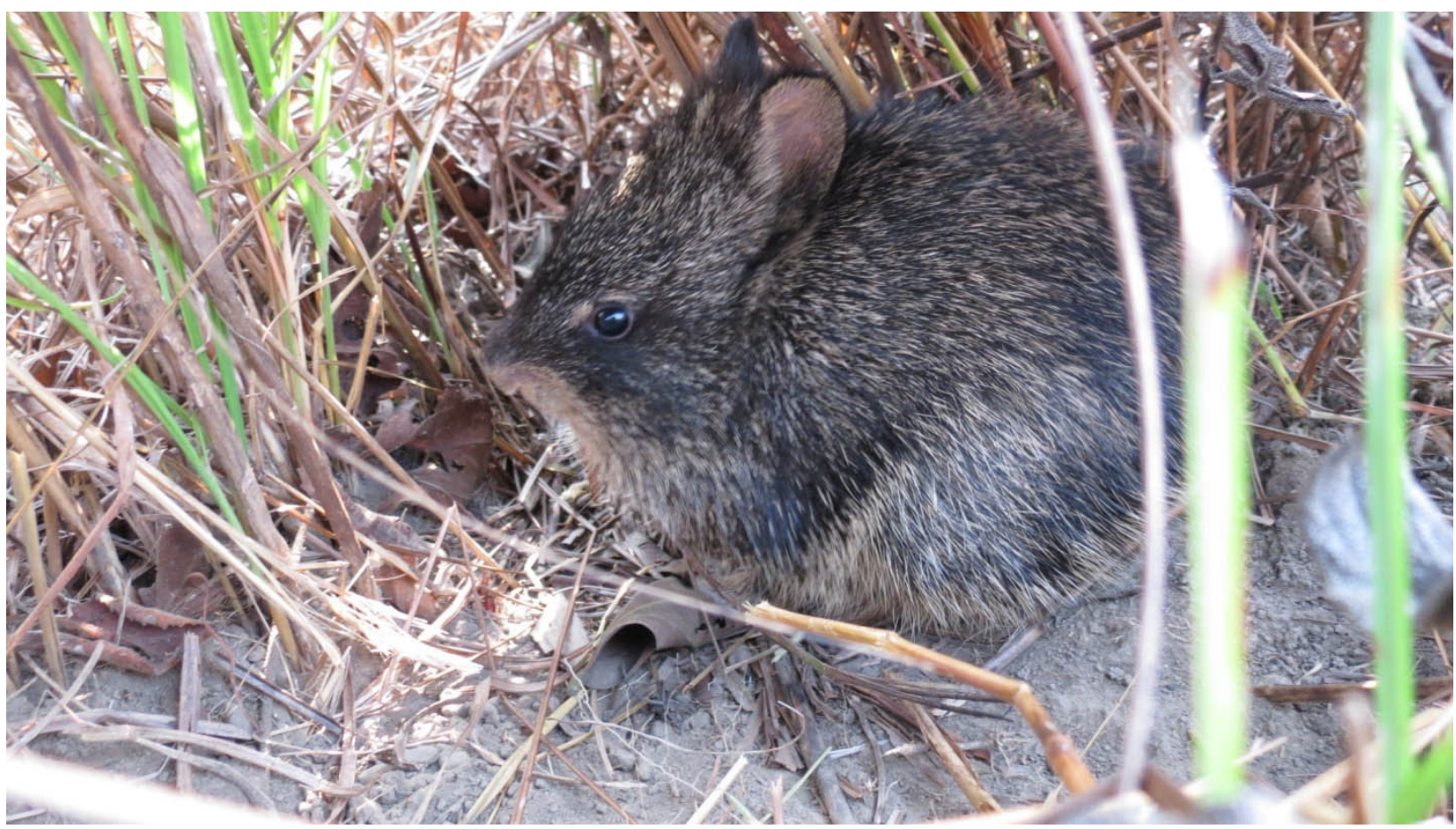

Figure 1 Hispid hare individual which was recorded in Chitwan National Park in 2016, as captured by camera-traps. The present recording is the 2nd observation of the species in the region since 1984.

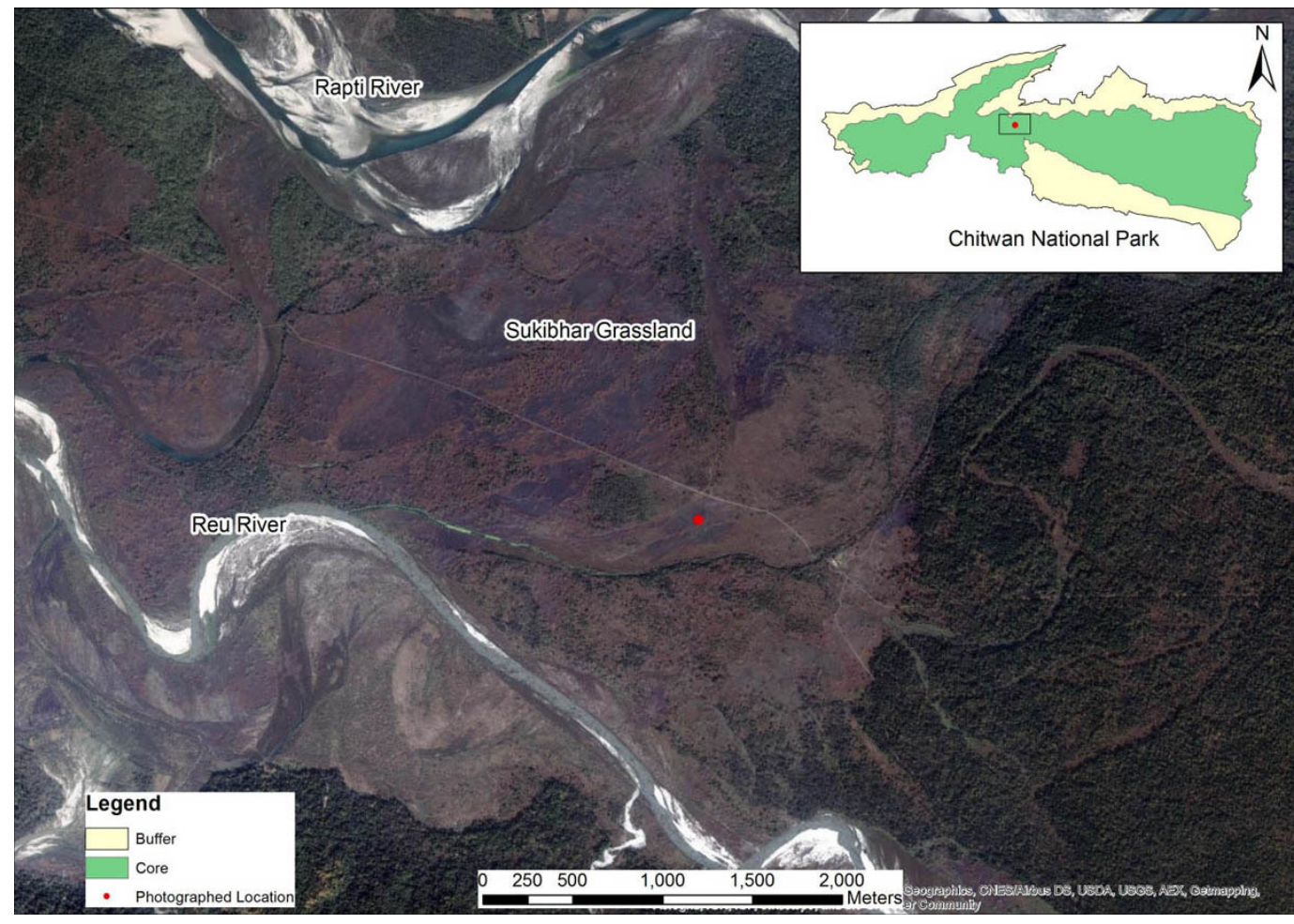

Figure 2 Locality of the hispid hare observation, the second realized after 32 years in Chitwan National Park. The sighting took place in the $30^{\text {th }}$ of January 2016.

between the park headquarters and the Tiger Top Jungle Lodge) and to the east of the Tiger Top Jungle Lodge. The area where the hare was found can be described as the floodplains of Rapti and Reu Rivers, riparian ecosystems which support a broad range of endangered species including tigers, rhinos (Rhinoceros unicornis) and other threatened fauna. On these floodplains, a very small patch of grassland remains (about $10 \mathrm{ha}$ ), known as the primary grassland habitat for Bengal florican (Houbaropsis bengalensis) and hispid hares. There have been continual sightings of Bengal floricans there since 2001, but not of hispid hares, up to the date.
The survey was carried out to target grassland birds including the Bengal florican, and observations were made from road transects with a vehicle and from a vantage points (machan - a platform built high in large trees, used originally for hunting game animals and observing animals in wildlife reserves). Various mammal and bird species were recorded during the survey. Additional habitat and vegetation surveys were conducted by using standard line transects (with a total of nine transects, each transect line $1 \mathrm{~km}$ long and lines set apart at $100 \mathrm{~m}$ intervals). Vegetation sampling was also realized at $100 \mathrm{~m}$ intervals along the transects, and grass counts were conducted using $1 \mathrm{~m} \times 1 \mathrm{~m}$ square plots. 
Vegetation along the line transect where the hispid hare was found was dominated by grass species Saccharum munja (70\% of the coverage area), Saccharum bengalense (10\% of the coverage area) and Imperata cylindrica (20\% of the coverage area). In protected areas in Nepal, grassland burning is used as a management tool by park authorities to create new grass shoots for grazing animals. Annual burning, plus cutting are part of current grassland management practices used by local people (Bhatta 1999). Since 2001, park authorities manage the grassland on an annual basis during winter seasons (by cutting grass manually, drying and burning it). To the date, possible downstream effects of current grassland management are not known, although continuous grassland burning in protected areas might become a possible threat to rare hispid hares. Therefore, an immediate assessment of the status and habitat of hispid hares in the CNP is recommended, as well as to explore new possible distribution areas for the species.

\section{Aknowledgements}

We would like to thank Dr. Diana J. Bell helping us to identification of the species. We would like to acknowledge Mr. Ram Chandra Kandel (Chief Warden of CNP), and colleagues Mr. Abhinay Pathak, Mr. Rishi Ram Dhakal and Mr. Pradeep Joshi for their support.

\section{References}

Aryal A, Brunton D, Ji W, Yadav H, Adhikari B, Raubenheimer D (2012) Diet and habitat use of hispid hare Caprolagus hispidus in Shuklaphanta Wildlife Reserve Nepal. Mammal Study 37(2), 147-154.

Aryal A, Yadav HK (2010) First cameras trap sighting of critically endangered hispid hare (Caprolagus hispidus) in Shuklaphanta wildlife reserve-Nepal. World Applied Science Journal, 9, 367-371.

Bell DJ (1987) Study of the Biology and Conservation Problems of the Hispid Hare. Final Report. University of East Anglia, England.

Bhatta N (1999) Impact of Burning and Grazing on Vegetation Composition and above Ground Biomass Production in Mangalsera Grassland of RSWR, Nepal. M.Sc. Thesis, Tribhuvan University, Nepal, 69 pp.

Maheswaran G, Smith AT (2008) Caprolagus hispidus.
The IUCN Red List of Threatened Species 2008: e.T3833A10112058. http://dx.doi.org/10.2305/IUCN. UK.2008.RLTS.T3833A10112058.en. Downloaded on O5 November 2017.

Nath NK, Machary K(2015) An ecological assessment of Hispid Hare Caprolagus hispidus (Mammalia: Lagomorpha: Leporidae) in Manas National Park, Assam, India. Journal of Threatened Taxa 7(15), 8195-8204.

Tandon P, Karki K, Dhakal B, Aryal A (2013) Tropical grasslands supporting the endangered hispid hare (Caprolagus hispidus) population in the Bardia National Park, Nepal. Current Science 105(5), 691-694.

Yadav BP, Sathyakumar S, Koirala RK, Pokharel C (2008) Status, distribution and habitat use of hispid hare (Caprolagus hispidus) in Royal Suklaphanta Wildlife Reserve, Nepal. Tiger paper 35(3), 8-14.

\section{Biography}

Mr Bed Bahadur Khadka, Mr. Bhupendra Prasad Yadav and Mr. Nurendra Aryal are wildlife officers and they are working at Department of National Park and Wildlife Conservation, Ministry of Forests and Soil Conservation, Nepal for more than 10 years. Dr. Achyut Aryal is conservation biologist and working for wildlife research and conservation from last 10 years.

\section{Citation}

Khadka BD, Yadav BP, Aryal N, Aryal A (2017) Rediscovery of the hispid hare (Caprolagus hispidus) in Chitwan National Park, Nepal after three decades. Conservation Science, 1: 10-12 